agriTECH, 40 (1) 2020, 31-38

\title{
Sifat Fisikokimia dan Profil Asam Lemak Minyak Ikan dari Kepala Kakap Merah (Lutjanus malabaricus)
}

\author{
Physicochemical Properties and Fatty Acid Profiles of Fish Oil from Red Snapper (Lutjanus malabaricus) Head \\ Desiana Nuriza Putri, Yessi Maulidhia Nugrahani Wibowo, Erika Novena Santoso*, \\ Putri Romadhania

\begin{abstract}
Jurusan Ilmu dan Teknologi Pangan, Fakultas Pertanian Peternakan, Universitas Muhammadiyah Malang, Jl. Raya Tlogomas No. 246, Malang, Jawa Timur 65144, Indonesia

*Penulis korespondensi: Erika N.S, Email: erikanovenasantoso@gmail.com
\end{abstract}

Tanggal submisi: 26 Juni 2019; Tanggal penerimaan: 16 Oktober 2019

\begin{abstract}
ABSTRAK
Industri pengolahan ikan kakap merah (Lutjanus malabaricus) menghasilkan limbah padat dan produk samping dengan jumlah lebih dari 50\%, sehingga hasil samping pengolahan ikan kakap merah berupa kepala berpotensi sebagai sumber minyak ikan kaya omega-3. Penelitian ini bertujuan untuk mengetahui metode rendering dan lama ektraksi minyak ikan kaya omega-3 dari limbah ikan kakap merah yang menghasilkan minyak ikan dengan kualitas terbaik. Kepala ikan kakap merah diambil dari salah satu industri fillet ikan di Pasuruan, Jawa Timur, Indonesia. Rancangan percobaan yang digunakan dalam penelitian ini adalah Rancangan Acak Kelompok (RAK) dengan 2 faktor perlakuan yaitu metode dan lama ekstraksi, dimana metode yang digunakan adalah rendering basah dan rendering kering dengan lama ekstraksi 1, 2, dan 3 jam dengan ulangan sebanyak 3 kali. Hasil penelitian yaitu didapatkan minyak ikan terbaik pada perlakuan rendering basah dan lama ekstraksi selama 1 jam dengan bilangan peroksida 0,98 meq/kg, kadar asam lemak bebas 1,02\%, angka asam 2,02\%, rendemen 9,02\%, kadar air 4,22\% (bb), tingkat kecerahan (L) 43,5, tingkat kemerahan (a) -0,9, dan tingkat kekuningan (b) 2,7, serta memiliki 31 jenis asam lemak dengan kandungan asam palmitat sebagai asam lemak dominan. Minyak ikan hasil penelitian ini juga mengandung omega-3 sebanyak 14,02\% serta memiliki kandungan AA, DHA dan EPA.
\end{abstract}

Kata kunci: Ekstraksi; minyak; omega-3; rendering

\begin{abstract}
Red snapper processing industry (Lutjanus malabaricus) produces more than $50 \%$ solid waste and by-products, so the by-product of red snapper processing, viz., the fish head is a potential source of omega-3. This study aimed to determine the rendering method and extraction time, producing the best quality fish oil that is rich in omega-3 from the red snapper head. The samples were taken from a fish fillet industry in Pasuruan, East Java, Indonesia. Randomized Block Design (RBD) with two factors has been used to evaluate different rendering methods (wet and dry rendering) and extraction time (1,2, and 3 hours) in triplicate. The results showed that the best fish oil was produced by wet rendering method in 1 hour of extraction time, achieving peroxide number $0.98 \mathrm{meq} / \mathrm{kg}$, free fatty acid $1.02 \%$, acid number $2.02 \%$, extraction yield $9.02 \%$, water content $4.22 \%$ (wb), brightness (L) 43.5 , redness level (a) -0.9, and yellowish level (b) 2.7. The fish oil consisted of 31 types of fatty acids with palmitic acid as the major fatty acid. Additionally, the oil also contained omega-3 (14.02\%) as well as AA, DHA, and EPA.
\end{abstract}

Keywords: Extraction; oil; omega-3; rendering

DOI: http://doi.org/10.22146/agritech.47039

ISSN 0216-0455 (Print), ISSN 2527-3825 (Online) 


\section{PENDAHULUAN}

Omega-3 adalah salah satu jenis asam lemak esensial yang berasal dari sumber hewani yaitu ikan. Salah satu jenis ikan yang tinggi akan omega-3 adalah ikan kakap merah (Lutjanus sp.). Menurut Data Statistik Kementerian Kelautan dan Perikanan (2017) produksi ikan kakap di Indonesia sebesar 8.431 ton dan ditargetkan akan mengalami peningkatan sebesar $17,31 \%$ dari tahun 2015-2019. Indonesia merupakan top producer ikan kakap merah yang berkontribusi sebesar $84 \%$ dan dbandingkan dengan ikan-ikan universal lainnya, ikan kakap merah merupakan penyumbang ekonomi negara Indonesia sebesar 8,2\%(KKP, 2018).

Persentase daging ikan yang termanfaatkan dalam industri pengolahan fillet ikan kakap merah sebanyak 40-50\%, selebihnya limbah ikan kakap merah berupa kepala, ekor, sirip, jeroan, tulang, sisik, insang dan kulit belum termanfaatkan secara optimal (Ifa dkk., 2018). Menurut Abbas dkk. (2009) ikan kakap merah memiliki asam lemak omega-3, asam oleat dan palmitat sebagai asam lemak dominan. Saraswati (2013) melaporkan kandungan asam lemak tak jenuh ganda pada ikan kakap merah (Lutjanus sp.) sebesar 22,55\% dan total asam lemak tak jenuh tunggal sebesar $7,17 \%$. Berdasarkan data tersebut, kepala ikan kakap berpotensi menjadibahan baku minyak ikan kaya omega-3 melalui proses ekstraksi.

Beberapa penelitian mengenai ekstraksi minyak ikan dari produk samping ikan antara lain ekstraksi minyak ikan dari by product ikan trout (Fiori dkk., 2012), ekstraksi limbah ikan Cyprinus carpio (Crexi dkk., 2010), persentase asam lemak minyak ikan lele yang diekstrak dari bagian tubuh yang berbeda (Thammapat dkk., 2010) dan Eka dkk. (2016) melaporkan bahwa rendering basah merupakan teknik rendering terbaik untuk mengekstrak minyak ikan. Kamini dkk. (2016) menyatakan ekstraksi hasil samping pengolahan patin memiliki karakteristik minyak ikan patin terbaik hasil ekstraksi rendering kering diperoleh pada perlakuan suhu $50{ }^{\circ} \mathrm{C}$ selama 2 jam menghasilkan rendemen $45,17 \%$, peroxide value $2,77 \mathrm{meq} / \mathrm{kg}$, FFA $0,83 \%$, p-anisidin 2,86 meq/kg, total oksidasi (totox) 8,39 $\mathrm{meq} / \mathrm{kg}$, rendemen tertinggi didapatkan pada ekstraksi dengan suhu $70-80{ }^{\circ} \mathrm{C}$ yaitu sebesar $72,50-76,48 \%$.

Metode ekstraksi minyak ikan yang sering digunakan adalah rendering basah dan rendering kering karena metode ini tidak memerlukan bahan kimia selama proses dan ramah lingkungan karena tidak menghasilkan polusi dan mudah diaplikasikan untuk pengolahan limbah (Jayathilakan dkk., 2012; Sindt, 2017). Rendering basah adalah metode yang paling banyak digunakan untuk produksi minyak ikan (FAO, 1995) karena mampu menghasilkan rendemen minyak ikan yang tinggi. MenurutKamini dkk. (2016), rendemen tertinggi diperoleh pada suhu $70^{\circ} \mathrm{C}$ dan $80{ }^{\circ} \mathrm{C}$ berkisar $72,50-76,48 \%$ dan untuk menghasilkan minyak ikan yang sesuai standar membutuhkan suhu dan lama ekstraksi yang optimal (IFOS, 2011).

Rendering merupakan metode yang masih relevan dengan industri di seluruh dunia dan merupakan metode ekstraksi terbaik untuk mengolah produk samping hewan (Leiva, 2018). Meskipun banyak proses rendering yang berbeda telah diaplikasikan untuk ekstraksi selama bertahun-tahun, tidak ada laporan mengenai metode rendering yang digunakan dalam mengekstrak minyak ikan dari produk samping ikan kakap merah untuk menghasilkan rendemen tinggi dan mengurangi kerusakan selama proses ekstraksi. Penelitian ini bertujuan untuk mengetahui metode dan durasi ekstraksi minyak ikan kaya omega-3 dari kepala ikan kakap merah yang menghasilkan minyak ikan dengan kualitas terbaik.

\section{METODE PENELITIAN}

\section{Bahan}

Penelitian ini menggunakan bahan baku berupa kepala ikan kakap yang didapatkan dari salah satu industri fillet ikan yaitu PT. Inti Luhur Fuja Abadi, Pasuruan, Jawa Timur. Kepala ikan kakap merah yang digunakan adalah kepala ukuran sekitar 200-300 g per kepala. Bahan lain yang digunakan meliputi aquades, $\mathrm{KOH}$, etanol 95\%, indikator PP, asam asetat glasial, kloroform, KI, indikator amilum 1\%, maltodekstrin dan sodium thiosulfat yang didapatkan dari Laboratorium Ilmu dan Teknologi Pangan, Universitas Muhammadiyah Malang.

\section{Alat}

Beberapa alat yang digunakan antara lain adalah oven (Binder WTC1200), sentrifuse (Hettich Mikro 220R), seperangkat alat analisis GC-FID (Perkin Elmer), panci, talenan, pisau, pipet tetes, corong pisah, timbangan, panci steam, wadah alumunium, kain saring, botol kaca gelap, termometer, Erlenmeyer, hot plate, kompor, buret, dan pipet ukur.

\section{Preparasi Bahan}

Limbah kepala ikan kakap merah dibersihkan, dipotong dengan ukuran $0,5 \times 0,5 \times 1 \mathrm{~cm}$ untuk mengoptimalkan pengeluaran minyak saat ekstraksi dan ditimbang sebanyak $250 \mathrm{~g}$. Setelah itu limbah kepala ikan kakap disimpan dalam kondisi beku sampai waktu ekstraksi. 


\section{Ekstraksi Minyak Ikan dengan Metode Rendering Basah}

Metode ekstraksi minyak ikan berdasarkan metode Kamini dkk. (2016) yang dimodifikasi. Limbah kepala ikan kakap merah yang sudah dipreparasi sebanyak 250 g ditambahkan aquades (1:3). Kemudian diekstraksi dengan menggunakan suhu $80^{\circ} \mathrm{C}$ selama 1 , 2, dan 3 jam. Minyak yang berada pada permukaan air dipisahkan dengan cara diambil dengan sendok secara perlahan. Minyak yang diperoleh kemudian dicampur dengan minyak yang diperoleh dari pemerasan limbah kepala ikan kakap merah. Setelah itu dilakukan sentrifugasi (4000 rpm, $25^{\circ} \mathrm{C}$, 4 menit). Setelah itu dihitung kadar rendemen minyak yang didapatkan dan dilakukan pengujian minyak ikan.

\section{Ekstraksi Minyak Ikan dengan Metode Rendering Kering}

Metode ekstraksi minyak ikan berdasarkan metode Kamini dkk. (2016) yang dimodifikasi. Limbah kepala ikan kakap merah yang sudah dipreparasi sebanyak 250 g dimasukkan kedalam panci yang terdapat saringan (panci steam) dipanaskan menggunakan oven (80 $\left.{ }^{\circ} \mathrm{C}\right)$ selama 1, 2, dan 3 jam. Minyak yang tertampung disentrifugasi (4000 rpm, $25{ }^{\circ} \mathrm{C}, 4$ menit). Setelah itu dihitung rendemen minyak yang didapatkan dan dilakukan pengujian minyak ikan.

\section{Analisis Sifat Fisikokimia Minyak Ikan}

Rancangan percobaan dalam penelitian ini adalah Rancangan Acak Kelompok (RAK) dengan 2 variabel bebas yaitu jenis rendering dan lama ekstraksi. Analisis sifat fisikokimia minyak ikan antara lain analisis asam lemak bebas (ALB), bilangan peroksida, angka asam (AOAC, 1995), rendemen (Nazir dkk., 2017), kadar air (AOAC, 2005), dan analisis warna serta kandungan asam lemak menggunakan kromatografi gas (GC-FID) (AOCS, 1993; AOAC, 2000; Nimal dkk., 2006 dan SNI, 1992).

\section{Analisis Profil Asam Lemak Minyak Ikan}

Analisis profil asam lemak minyak ikan dilakukan pada minyak hasil ekstraksi dengan karakteristik terbaik berdasarkan parameter sifat fisik dan kimia. Prosedur analisa yaitu minyak ditimbang $2-3 \mathrm{~g}$ dan ditambahkan $1,5 \mathrm{~mL}$ larutan $\mathrm{KOH}$ 0,5 M dalam methanol (tahap metilasi). Larutan dipanaskan sampai suhu $\pm 100^{\circ} \mathrm{C}$ dan didinginkan hingga suhu kamar, lalu ditambahkan $\mathrm{BF}_{3}$ $20 \%$ dalam methanol, kemudian dipanaskan kembali pada suhu $\pm 100{ }^{\circ} \mathrm{C}$. Selanjutnya larutan didinginkan dan dikocok sampai suhu larutan sekitar $30^{\circ} \mathrm{C}$ dan ditambahkan $\mathrm{NaCl}$ jenuh dan heksana, kemudian dihomogenkan selama \pm 2 menit. Setelah terbentuk dua lapisan, pindahkan lapisan fase organik ke tube 2 $\mathrm{mL}$ yang berisi $\mathrm{Na}_{2} \mathrm{SO}_{4}$ anhidrat dan didiamkan selama 15 menit. Larutan dimasukkan ke dalam vial $2 \mathrm{~mL}$. Deteksi kandungan asam lemak minyak dilakukan menggunakan GC-FID Perkin Elmer. Suhu inlet diatur pada suhu $225^{\circ} \mathrm{C}$. Sampel sebanyak $0,1 \mu \mathrm{L}$ di injeksikan ke dalam alat GC-FID yang dioperasikan menggunakan kolom Supelco SP2560 dengan spesifikasi panjang kolom $100 \mathrm{~m}$, diameter $0,25 \mathrm{~mm}$ dan ketebalannya 0,2 $\mu \mathrm{m}$. Gas pembawa yang digunakan berupa $\mathrm{N}_{2}$ dengan kecepatan aliran $18 \mathrm{~cm} /$ detik. Oven di-setting pada suhu $240{ }^{\circ} \mathrm{C}$ dengan tingkat kenaikan suhu $2,5^{\circ} \mathrm{C}$ /menit. Hasil deteksi menggunakan FID dapat menunjukkan tipe asam lemak yang terdapat dalam ekstrak minyak ikan, meliputi asam lemak jenuh, asam lemak tak jenuh tunggal (Mono Unsaturated Fatty Acid), PUFA (Poly Unsaturated Fatty Acid), dan total asam lemak dalam sampel. Persentase setiap jenis asam lemak dihitung berdasarkan kromatogram.

\section{Analisis Statistik}

Hasil analisis sifat fisik kimia minyak ikan dianalisis secara satistik (Anova) menggunakan perangkat lunak SPSS 20 kemudian dilakukan uji lanjut metode Duncan Multiple Range Test (DMRT) dengan taraf kepercayaan $5 \%$.

\section{HASIL DAN PEMBAHASAN}

\section{Rendemen}

Metode ekstraksi yang digunakan pada penelitian ini adalah rendering dengan lama ekstraksi yang berbeda pada suhu $80^{\circ} \mathrm{C}$. Perlakuan metode dan lama ekstraksi berpengaruh signifikan terhadap rendemen minyak ikan yang dihasilkan $(p<0,05)$. Rendemen minyak ikan terbesar diperoleh dari perlakuan ekstraksi rendering basah selama 1 jam yaitu sebesar $\pm 9 \%$ (Tabel 1 ). Hasil ini menyerupai hasil penelitian yang telah dilakukan oleh Hastarini dkk. (2012) yang menunjukkan bahwa kepala merupakan salah satu bagian tubuh ikan patin

Tabel 1 . Rendemen minyak ikan hasil ekstraksi

\begin{tabular}{ccc}
\hline Metode & Lama ekstraksi & Rendemen (\%) \\
\hline Rendering basah & 1 jam & $9,02^{\mathrm{c}}$ \\
& 2 jam & $1,22^{\mathrm{b}}$ \\
\multirow{3}{*}{ Rendering kering } & 3 jam & $1,03^{\mathrm{ab}}$ \\
& 1 jam & $0,85^{\mathrm{ab}}$ \\
& 2 jam & $0,54^{\mathrm{ab}}$ \\
& 3 jam & $0,26^{\mathrm{a}}$ \\
\hline
\end{tabular}

Keterangan: Huruf yang berbeda pada kolom yang sama menunjukkan perbedaan yang signifikan $(p>0,05)$ 
yang berpotensi besar sebagai bahan baku minyak ikan karena menghasilkan rendemen minyak ikan sebesar 9,84\% melalui metode ekstraksi rendering basah pada suhu $70{ }^{\circ} \mathrm{C}$ selama 15 menit.

Tingginya rendemen minyak ikan yang dihasilkan melalui ekstraksi metode rendering basah kemungkinan dipengaruhi oleh adanya penambahan air sehingga mempermudah pemisahan minyak dari bahan. Sebagaimana dijelaskan oleh Qaishum dkk. (2013) bahwa pemanasan bahan, minyak atau lemak akan terpisah atau mengapung pada permukaan air sehingga minyak atau lemak dapat dipisahkan. Penambahan air pada ekstraksi rendering basah berperan dalam menggumpalkan protein ikan, sehingga minyak dan bagian padatan dari ikan dapat dipisahkan. Hal ini sesuai dengan hasil penelitian Rubio-rodríguez dkk. (2012) yang menyatakan bahwa metode rendering basah adalah metode ektraksi minyak ikan terbaik karena melibatkan tiga prinsip dari ekstraksi yaitu memasak, pemberian tekanan dan sentrifugasi.

Rendemen minyak ikan yang dihasilkan melalui metode rendering basah selama 1 jam lebih tinggi dibandingkan rendemen minyak ikan yang dihasilkan melalui rendering basah selama 2 maupun 3 jam. Hal ini mungkin berkaitan dengan semakin banyaknya trigliserida yang terdegradasi dengan semakin bertambahnya lama ekstraksi, sehingga menyebabkan terbentuknya asam lemak bebas yang semakin banyak serta menghasilkan rendeman minyak ikan dengan jumlah kecil.

\section{Bilangan Peroksida}

Pengujian bilangan peroksida dilakukan untuk mengetahui kualitas ekstrak minyak ikan, ketengikan yang terjadi juga dapat diketahui melalui bilangan peroksida. Interaksi metode dan lama ekstraksi yang berbeda berpengaruh nyata $(p<0,05)$ terhadap bilangan peroksida minyak ikan kepala kakap, peningkatan lama ekstraksi sebanding dengan senyawa peroksida minyak ikan yang dihasilkan. Bilangan peroksida juga dipengaruhi oleh metode ekstraksi yang digunakan. Nilai terendah diperoleh dari ekstraksi metode rendering basah selama 1 jam yaitu sebesar 0,98 meq/kg (Tabel 2).

Metode rendering basah merupakan metode yang dapat menghasilkan minyak dengan nilai bilangan peroksida terendah, hal ini dikarenakan metode rendering basah menghasilkan penyebaran panas lebih merata karena adanya air sebagai penghantar panas ke seluruh bahan. Hal ini sesuai dengan hasil penelitian Eka dkk. (2016) bahwa ekstraksi minyak ikan lele menghasilkan ekstrak minyak dengan bilangan peroksida lebih tinggi pada metode rendering kering
Tabel 2. Bilangan peroksida minyak ikan hasil ekstraksi

\begin{tabular}{ccc}
\hline Metode & Lama ekstraksi & $\begin{array}{c}\text { Peroksida } \\
(\mathrm{meq} / \mathrm{kg})\end{array}$ \\
\hline Rendering basah & 1 jam & $0,98^{\mathrm{a}}$ \\
& 2 jam & $37,90^{\mathrm{d}}$ \\
Rendering kering & 3 jam & $5,95^{\mathrm{b}}$ \\
& 1 jam & $5,95^{\mathrm{b}}$ \\
& 2 jam & $10,79^{\mathrm{c}}$ \\
& 3 jam & $59,64^{\mathrm{e}}$ \\
\hline
\end{tabular}

Keterangan: Huruf yang berbeda pada kolom yang sama menunjukkan perbedaan yang signifikan $(p>0,05)$

yaitu 3,49 meq/kg sedangkan minyak ikan dengan metode rendering basah adalah $1,08 \mathrm{meq} / \mathrm{kg}$. Menurut Edwar dkk. (2011) peningkatan bilangan peroksida dapat diakibatkan oleh terputusnya ikatan rangkap akibat suhu pemanasan. Minyak ikan hasil ekstraksi rendering basah selama 1 jam memiliki nilai bilangan peroksida yang lebih baik dibandingkan minyak ikan hasil samping pengasapan ikan patin yang dihasilkan dalam penelitian Sari dkk. (2016) yaitu sebesar 4,88 $\mathrm{meq} / \mathrm{kg}$ dengan menggunakan metode rendering basah selama 8 jam. Selain itu hasil penelitian Julaikha (2014) menghasilkan bilangan peroksida sebesar 11,67 meq/ kg untuk minyak ikan murni berbahan baku belly flap. Faktor-faktor yang mempengaruhi perbedaan bilangan peroksida adalah jenis dan kondisi bahan baku yang berbeda serta pemilihan metode ekstraksi (Sari dkk., 2016).

\section{Asam Lemak Bebas (ALB)}

Pengujian asam lemak bebas pada minyak ikan bertujuan untuk mengetahui seberapa jauh minyak mengalami oksidasi. Berdasarkan hasil pengujian, interaksi metode dan durasi ekstraksi tidak berpengaruh nyata terhadap asam lemak bebas minyak ikan kepala kakap merah $(p>0,05)$. Hal ini sejalan dengan pernyataan Kamini dkk. (2016) yang melaporkan suhu dan lama ekstraksi tidak berpengaruh signifikan terhadap kadar asam lemak bebas minyak ikan. Kadar asam lemak bebas minyak ikan hasil penelitian ini hampir sama dengan kandungan asam lemak bebas minyak ikan pada penelitian Kamini dkk. (2016) yaitu $<1,2 \%$.

Hasil analisis ALB ekstraksi minyak ikan hasil penelitian ini lebih kecil dibandingkan minyak ikan murni yaitu 5,64\% (Julaikha, 2014). ALB terbentuk karena reaksi hidrolisis trigliserida yang menghasilkan ikatan asam lemak dan gliserol terputus dan juga disebabkan oleh perpecahan serta oksidasi ikatan rangkap asam 


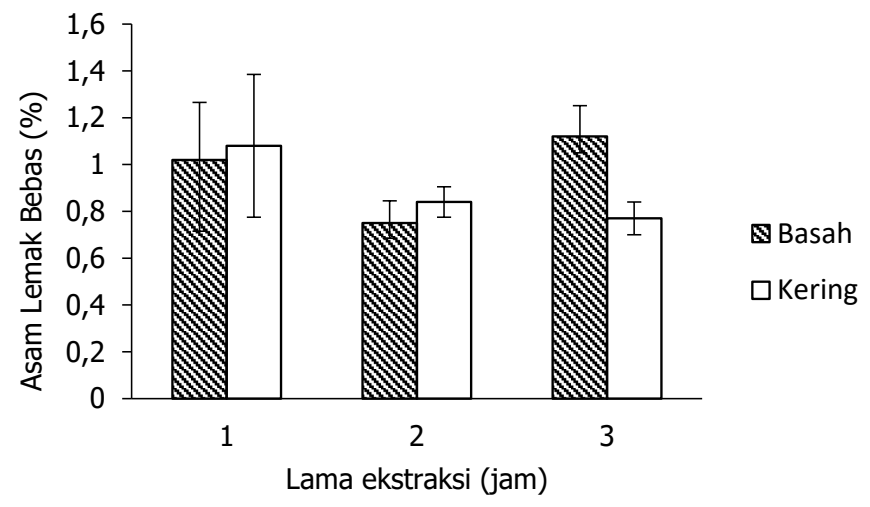

Gambar 1. Asam lemak bebas minyak ikan hasil ekstraksi

lemak (Crexi dkk., 2010; Deepika dkk., 2014). Asam lemak bebas merupakan salah satu indikator dalam menentukan kualitas minyak. Semakin buruk kualitas minyak ikan maka semakin besar nilai asam lemak bebas (Eka dkk., 2016). Kadar asam lemak bebas minyak ikan pada penelitian ini telah sesuai dengan standar ketentuan IFOMA (International Fish Meal and Oil Manufactured Assosiation), mutu minyak ikan yang baik jika mengandung asam lemak bebas 1-7\% (Aditia dkk., 2014).

Rendahnya kadar asam lemak bebas minyak ikan (Gambar 1) dikarenakan komposisi asam lemak minyak ikan kakap terbesar adalah asam oleat, yaitu asam lemak tak jenuh yang memiliki ikatan rangkap tunggal (MUFA) sehingga minyak lebih stabil dibandingkan asam lemak tak jenuh lainnya memiliki ikatan rangkap lebih banyak (PUFA), hal ini sesuai dengan Suroso (2013) yang menyatakan bahwa semakin banyak jumlah ikatan rangkap yang terdapat dalam susunan asam lemak, maka akan lebih reaktif terhadap oksigen sehingga lebih mudah teroksidasi dan didukung oleh Sartika (2009) yang menyatakan bahwa tidak terjadi kerusakan pada asam oleat akibat pemanasan hingga suhu $200^{\circ} \mathrm{C}$ selama 30 menit dan baru akan mengalami kerusakan menjadi trans setelah penggorengan kedua.

\section{Angka Asam}

Perlakuan metode ekstraksi dan lama ekstraksi tidak berpengaruh nyata terhadap angka asam minyak ikan kepala kakap merah $(p>0,05)$. Angka asam menggambarkan banyaknya kandungan ALB pada minyak yang terbentuk akibat reaksi hidrolisis triasilgliserol (Panagan dkk., 2011).

Kualitas minyak semakin turun apabila angka asam semakin besar. Menurut SNI angka asam dinyatakan dengan jumlah $\mathrm{KOH}$ dalam $\mathrm{mg}$ yang dibutuhkan untuk menetralkan 1 gram ALB. Angka asam juga

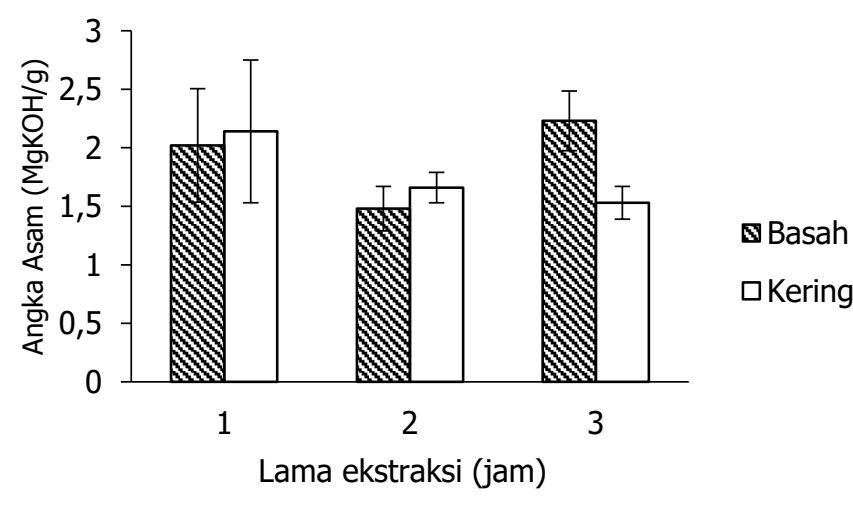

Gambar 2. Angka asam minyak ikan hasil ekstraksi

dinyatakan dalam \% yang ekivalen terhadap asam oleat (Maulana dkk., 2014). Nilai angka asam minyak ikan dalam penelitian ini yaitu $1,48-2,23 \mathrm{mg} \mathrm{KOH} / \mathrm{g}$ sampel (Gambar 2), nilai ini sudah memenuhi standar yang telah ditentukan. Menurut International Fishmeal and Oil Manufactures Association yaitu standar angka asam sebesar $7 \mathrm{mg} \mathrm{KOH} / \mathrm{g}$ sampel (Husain dkk., 2016). Penelitian Istiqlaal (2018) menghasilkan minyak tulang ikan tuna sebesar 4,32-5,88 $\mathrm{mg} \mathrm{KOH} / \mathrm{g}$, yang berarti masih jauh lebih tinggi dari angka asam minyak ikan kepala kakap merah pada penelitian ini. Bilangan asam merupakan parameter untuk menentukan komponen asam selain lemak dan adanya FFA. Kesegaran bahan mentah dan komposisi minyak berpengaruh terhadap bilangan asam suatu minyak (Mohanarangan, 2012).

\section{Kadar Air}

Metode dan lama ekstraksi tidak berpengaruh signifikan terhadap kadar air ekstrak minyak ikan (Gambar 3). Pada ekstraksi rendering basah terdapat penambahan air yang berfungsi sebagai pelarut, namun hal tersebut tidak menyebabkan perbedaan kadar air yang signifikan pada minyak ikan yang dihasilkan. Berdasarkan penelitian Fadillah (2014) bahwa proses ekstraksi tidak berpengaruh terhadap kadar air sampel minyak yang dihasilkan. Hal ini disebabkan proses sentrifugasi pada proses ekstraksi telah efektif dalam memisahkan air, minyak dan daging buah (Sarungallo, 2015).

Kadar air yang tinggi dalam minyak ikan tidak dikehendaki karena semakin besar kandungan air dalam minyak, kemungkinan penurunan kualitas minyak selama masa penyimpanan akan semakin besar. Hal itu disebabkan karena air memiliki kemampuan untuk menghidrolisis minyak dan menghasilkan asam lemak bebas yang berperan sebagai prekusor ketengikan minyak. Standar yang terdapat dalam 


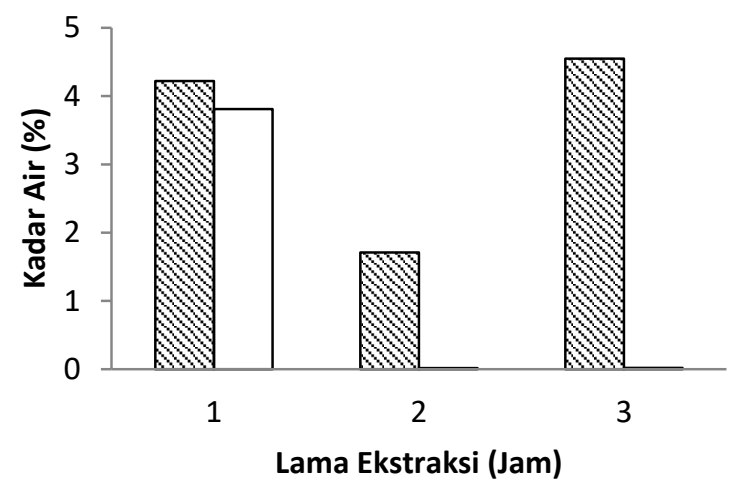

Gambar 3. Kadar air minyak ikan hasil ekstraksi

IFOMA (International Fishmeal and Oil Manufactured Assosiation) untuk kadar air crude fish oil yaitu berkisar antara $0,5-1 \%$.

\section{Warna}

Metode rendering dan lama ekstraksi minyak ikan kakap tidak mempengaruhi warna minyak (Tabel 3). Hal ini dikarenakan suhu yang digunakan pada proses ekstraksi adalah $80^{\circ} \mathrm{C}$. Ekstrak minyak ikan cenderung berwarna keruh kekuningan. Warna kekuningan pada minyak ikan yang dihasilkan menurut Sabar dkk. (2015) disebabkan oleh adanya zat pigmen dalam minyak limbah ikan, yaitu pigmen alami dan senyawa hasil degradasi zat warna alami. Terdapat beberapa senyawa seperti karoten, xantofil dan antosianin yang ikut terekstrak selama proses ekstraksi dapat menyebabkan minyak yang dihasilkan berwarna kuning, kuning kecoklatan, kehijau-hijauan dan kemerah-merahan.

Minyak ikan yang dihasilkan berwarna keruh karena proses kristalisasi pada kandungan selain minyak yang terjadi ketika minyak ikan berada pada suhu ruang (Eka \& Rochima, 2016). Estiasih dkk. (2009) menyatakan bahwa beberapa faktor yang mempengaruhi warna dan

Tabel 3. Warna minyak ikan hasil ekstraksi

\begin{tabular}{lcccc}
\hline \multicolumn{1}{c}{ Metode } & $\begin{array}{c}\text { Lama } \\
\text { ekstraksi }\end{array}$ & $\mathrm{L}$ & $\mathrm{a}$ & $\mathrm{B}$ \\
\hline Rendering & 1 jam & $43,50^{\mathrm{a}}$ & $-0,90^{\mathrm{a}}$ & $2,70^{\mathrm{a}}$ \\
basah & 2 jam & $53,90^{\mathrm{a}}$ & $0,90^{\mathrm{a}}$ & $15,25^{\mathrm{a}}$ \\
& 3 jam & $47,10^{\mathrm{a}}$ & $-0,70^{\mathrm{a}}$ & $7,20^{\mathrm{a}}$ \\
Rendering & 1 jam & $49,80^{\mathrm{a}}$ & $0,70^{\mathrm{a}}$ & $12,10^{\mathrm{a}}$ \\
kering & 2 jam & $49,50^{\mathrm{a}}$ & $0,30^{\mathrm{a}}$ & $11,30^{\mathrm{a}}$ \\
& 3 jam & $51,80^{\mathrm{a}}$ & $2,20^{\mathrm{a}}$ & $9,30^{\mathrm{a}}$ \\
\hline
\end{tabular}

Keterangan: Huruf yang berbeda pada kolom yang sama menunjukkan perbedaan yang signifikan $(p>0,05)$
Tabel 4. Komponen asam lemak minyak kepala ikan kakap merah hasil ekstraksi rendering basah selama 1 jam

\begin{tabular}{|c|c|c|}
\hline Nama asam lemak & Struktur & $\begin{array}{c}\text { Jumlah } \\
(\%)\end{array}$ \\
\hline Asam butirat & C $4: 0$ & 0,12 \\
\hline Asam kaproat & C 6:0 & 0,10 \\
\hline Asam kaprilat & C 8:0 & 0,45 \\
\hline Asam kaprat & C $10: 0$ & 0,37 \\
\hline Asam laurat & C $12: 0$ & 2,16 \\
\hline Asam tridekanoat & C $13: 0$ & 0,12 \\
\hline Asam miristat & C $14: 0$ & 7,53 \\
\hline asam pentadekanoat & C $15: 0$ & 1,27 \\
\hline Asam palmitat & C $16: 0$ & 29,87 \\
\hline Asam heptadekanoat & C $17: 0$ & 2,10 \\
\hline Asam stearat & C $18: 0$ & 13,55 \\
\hline Asam archidat & C $20: 0$ & 0,92 \\
\hline Asam heneikosanoat & C 21:0 & 0,31 \\
\hline Asam behenat & C 22:0 & 0,91 \\
\hline Asam trikosanoat & C 23:0 & 0,46 \\
\hline Asam lignoserat & C $24: 0$ & 0,55 \\
\hline Total SFA & & 60,78 \\
\hline Asam miristoleat & C $14: 1$ & 0,35 \\
\hline Asam pentadekenoat & C $15: 1$ & 0,19 \\
\hline asam palmitoleat & C $16: 1$ & 7,19 \\
\hline Asam heptadekenoat & C $17: 1$ & 0,66 \\
\hline Asam oleat & C $18: 1$ & 10,40 \\
\hline Asam eikosenoat & C $20: 1$ & 0,80 \\
\hline Asam nervonat & C $24: 1$ & 0,98 \\
\hline Total MUFA & & 20,56 \\
\hline Asam linoleat & C $18: 2$ & 0,68 \\
\hline asam eikosadienoat & C $20: 2$ & 0,46 \\
\hline Asam dokosadienoat & C $22: 2$ & 0,12 \\
\hline Asam linolenat & C $18: 3$ & 0,12 \\
\hline Asam eikosatrienoat & C $20: 3$ & 0,37 \\
\hline asam arakidonat (AA) & C $20: 4$ & 3,14 \\
\hline Asam eikosapentaenoat (EPA) & C $20: 5$ & 3,04 \\
\hline Asam dokosaheksaenoat (DHA) & C $22: 6$ & 10,74 \\
\hline Total PUFA & & 18,65 \\
\hline Total Asam Lemak Omega-3 & & 14,02 \\
\hline Total Asam Lemak Omega 6 & & 4,06 \\
\hline Total Asam Lemak Omega 9 & & 10,40 \\
\hline
\end{tabular}

Keterangan:

SFA : Saturated Fatty Acid (asam lemak jenuh)

MUFA: Monounsaturated Fatty Acid (asam lemak tak jenuh tunggal)

PUFA : Polyunsaturated Fatty Acid (asam lemak tak jenuh ganda) 
kekeruhan minyak antara lain kadar asam lemak bebas yang mudah mengalami oksidasi primer dan oksidasi sekunder, jumlah adsorben yang digunakan dalam tahap pemurnian serta suhu dan lama proses ekstraksi.

\section{Profil Asam Lemak}

Minyak ikan kepala kakap mengandung 31 jenis asam lemak (Tabel 4). Minyak hasil ekstraksi dengan metode rendering basah selama 1 jam diperoleh profil asam lemak SFA>MUFA>PUFA. Hal ini sesuai dengan hasil penelitian Sanger dkk. (2018) minyak ikan kakap merah dan minyak ikan kakap putih (Afriyani, 2016) memiliki kandungan asam lemak jenuh (SFA) tertinggi diantara asam lemak lainnya (PUFA dan MUFA) yaitu sebesar $45,45 \%$ dan $27,97 \%$.

Asam lemak jenuh minyak ikan kepala kakap merah tertinggi adalah asam palmitat (C16:0) sebesar 29,87\%. Pada komponen asam lemak tak jenuh tunggal minyak ikan kepala kakap memiliki kandungan asam oleat (C 18:1) 10,40\%. Hasil penelitian Sanger dkk. (2018) minyak ikan kakap merah memiliki 8 jenis asam lemak dengan kandungan asam lemak jenuh tertinggi yaitu asam palmitat (C 16:0) sebesar 37,99\%, sedangkan kandungan asam lemak tak jenuh tunggal yang tertinggi yaitu asam oleat sebesar $18,49 \%$. Hal ini sejalan dengan hasil penelitian Hastarini (2013) yang menyatakan minyak ikan patin murni dari jenis jambal dan siam dengan asam lemak dominannya yaitu asam palmitat dan asam oleat. Minyak ikan kepala kakap merah memiliki kandungan omega-3 yang tertinggi dibandingkan dengan asam lemak omega 6 dan omega 9. Selain itu, minyak ikan ini mengandung AA, EPA dan DHA. Minyak ikan kepala kakap merah ini mengandung DHA sebesar 10,74\%. Minyak ikan kepala kakap merah dalam penelitian ini mengandung DHA lebih tinggi dibandingkan dengan minyak ikan kakap merah hasil penelitian Sanger dkk. (2018) yaitu sebesar 4,10\%, serta pada hasil penelitian Hastarini (2013) minyak kepala ikan patin siam memiliki kandungan AA, EPA dan DHA lebih rendah daripada minyak pada penelitian ini yaitu masing-masing sebesar 0,89\%, 0,45\% dan $0,95 \%$.

\section{KESIMPULAN}

Hasil penelitian dapat disimpulkan bahwa minyak ikan kepala kakap merah dengan kualitas terbaik yaitu pada perlakuan rendering basah dengan lama ekstraksi selama 1 jam, dengan bilangan peroksida 0,98 meq $/ \mathrm{kg}$, kadar asam lemak bebas 1,02\%, angka asam 2,02\%, rendemen 9,02\%, kadar air 4,22\%, tingkat kecerahan (L) 43,5, tingkat kemerahan (a) $-0,9$, dan tingkat kekuningan (b) 2,7. Minyak ikan kepala kakap merah memiliki 31 profil asam lemak dengan kandungan asam palmitat sebagai asam lemak dominannya. Minyak ikan hasil penelitian ini juga mengandung omega-3 sebanyak $14,02 \%$ serta memiliki kandungan AA, DHA dan EPA.

\section{UCAPAN TERIMA KASIH}

Penulis mengucapkan terima kasih kepada semua staff di Laboratorium Ilmu dan Teknologi Pangan, Universitas Muhammadiyah Malang.

\section{KONFLIK KEPENTINGAN}

Tidak ada konflik kepentingan terkait dengan naskah ini.

\section{DAFTAR PUSTAKA}

Aditia, P. R., Darmanto, Romadhon. (2014). Perbandingan Mutu Minyak Ikan Kasar yang diekstrak dari Berbagai Jenis Ikan yang Berbeda. Pengolahan dan Bioteknologi Hasil Perikanan, 3(3), 55-60. http://www.ejournal-s1. undip.ac.id/index.php/jpbhp

Afriyani, U. (2016). Profil Asam Lemak, Kolesterol dan Jaringan Skin of Fillet Ikan kakap Putih (Lates calcarifer) Segar dan Panggang. Institut Pertanian Bogor.

AOAC Official Method of Analysis. (2000). Oil and Fat. Chapter $41,26-28$

AOAC. (1995). Official Methods of Analysis of The Association of Analitycal Chemist. Washington D.C.

AOCS Official Method. (1993). Preparation of Methyl Esters of Long-Chain Fatty acid. Page 2-66

Crexi, V. T., Monte, M. L., Almeida, L., Soares, D. S., Antonio, L., \& Pinto, A. (2010). Production and refinement of oil from carp ( Cyprinus carpio ) viscera. Food Chemistry, 119(3), 945-950. https://doi.org/10.1016/j. foodchem.2009.07.050

Deepika, D., Vr, V., Julia, P., Kc, S., Sheila, T., Heather, M., \& Wade, M. (2014). Investigation on Oil Extraction Methods and its Influence on Omega-3 Content from Cultured Salmon. 5(12). https://doi.org/10.4172/21577110.1000401

Edwar Z., Suyuthie H., Yerizel E., dan Sulastri E. (2011). Pengaruh Pemanasan terhadap Kejenuhan Asam Lemak Minyak Goreng Sawit dan Minyak Goreng Jagung. J Indon Med Assoc.Abbas, K. A., Mohamed, A., \& Jamilah, B. (2009). Fatty acids in fish and beef and their nutritional values: $A$ review. 7(October), 37-42.

Eka, B., \& Rochima, E. (2016). Pengaruh Metode Rendering Terhadap Karakteristik Fisik , Kimia Dan Organoleptik Ekstrak Kasar Minyak Ikan Lele. VII(1), 1-5.

Estiasih T. (2009). Minyak Ikan, Teknologi dan Penerapannya untuk Pangan dan Kesehatan. Yogyakarta: Graha Ilmu. 
Fadillah, U. F. (2014). Characteristic Study of Coconut Oil Extracted by Dry or Hot Methods.

FAO. (1995). Code of Conduct for Responsible Fisheries. Food and Agricultural Organization of The United Nations. Rome.

Fiori, L., Solana, M., Tosi, P., Manfrini, M., Strim, C., \& Guella, G. (2012). Lipid profiles of oil from trout ( Oncorhynchus mykiss ) heads, spines and viscera : Trout by-products as a possible source of omega-3 lipids ? Food Chemistry, 134(2), 1088-1095. https://doi.org/10.1016/j. foodchem.2012.03.022

Hastarini. (2013). Karakteristik minyak ikan dari limbah pengolahan filet ikan patin siam (pangasius hypopthalmus) dan patin jambal (pangasius djambal). Jurnal Agritech Fakultas Teknologi Pertanian UGM, 32(4). https://doi.org/10.22146/agritech.9584

Husain, R., Suparmo, Harmayani, E., \& Hidayat, C. (2016). Kinetics Oxidation of Tuna Fish Oil ( Thunus $S p$ ) during Storage. 36(2).

Ifa, L., Teknologi, F., Universitas, I., Indonesia, M., Artiningsih, A., \& Indonesia, U. M. (2018). PEMBUATAN KITOSAN DARI SISIK IKAN KAKAP MERAH. (May), 1-5. https:// doi.org/10.33536/jcpe.v3i1.194

IFOS. (2011). Fish oil purity standards. http://www.omegavia. com/best-fishoilsupplement-3.

Istiqlaal, S. (2018). ( Thunnus albacares ) Extraction and Characteristics of Tuna ( Thunnus albacares ) Bone Oil. 141-152.

Jayathilakan, K., K. Sultana, K. Radhakrisna, and A. Bawa. (2012). Utilization of Byproducts and Waste Materials from Meat, Poultry and Fish Processing Industries: A review. J. Food Sci. Technol. 49: 278-293.

Julaikha, A. (2014). Karakteristik Minyak Ikan dari Belly Flap Patin Siam (Pangasius Hypopthalmus) pada Berbagai Tahap Proses Pemurnian. Institut Pertanian Bogor.

Kamini, Suptijah, P., Santoso, J., \& Sh, S. (2016). Extraction by Dry Rendering Methode and Characterization Fish Oil of Catfish Viscera Fat by Product of Smooked Fish Processing, 19. https://doi.org/10.17844/jphpi.2016.19.3.196

KKP .(2018). KKP 2018.pdf.

Leiva, A. (2018). Characterization of the animal by-product meal industry in Costa Rica : Manufacturing practices through the production chain and food safety. (March). https://doi.org/10.3382/ps/pey058/4942568

Maulana, I. T., Sukraso, \& Damayanti, S. (2014). Kandungan asam lemak dalam minyak ikan indonesia. Ilmu dan Teknologi Kelautan Tropis 8(1): 121-130. http://itk.fpik. ipb.ac.id/ej_itkt61

Mohanarangan, A. B. (2012). Extraction of omega-3 fatty acids from atlantic herring ( Clupea harengus ). Dalhousie University
Nazir, N., Diana, A., \& Sayuti, K. (2017). Physicochemical and Fatty Acid Profile of Fish Oil from Head of Tuna ( Thunnus albacares ) Extracted from Various Extraction Method. 7(2), 709-715.

Nimal Ratnayake, W.M. et.all. (2006). Evaluasi of the CP-Sil 88 dan SP-2560 GC columns Used in Recently Approved AOCS Official Method Ce 1h-05 : Determination of Cis, trans, saturated, monosaturated and polyunsaturated Fatty Acid in Vegetable or Non-ruminant Animal Oils and Fat by Capillary GLC Method. Jurnal AOCS, Vol.83, no.6

Qaishum dkk. (2011). (2013). Pengaruh Komposisi Katalis H-Zeolit pada Proses Pembuatan Plastisizer Menggunakan Minyak Limbah Ikan Patin dan Isobutanol.

Rubio-rodríguez, N., Diego, S. M. De, Beltrán, S., Jaime, I., Sanz, M. T., \& Rovira, J. (2012). Supercritical fluid extraction of fish oil from fish by-products : A comparison with other extraction methods. 109, 238-248. https:// doi.org/10.1016/j.jfoodeng.2011.10.011

Sabar, J., Feti F., Johnly A. R. (2015). Karakterisasi Minyak Ikan dari Pemurnian Limbah Ikan Tuna dengan Zeolit secara Kromatografi Kolom. Jurnal MIPA UNSRAT online 4 (2) 161-164

Sanger Natalia Winly, Pontoh Julius, Momuat Lidya. (2018). Komposisi Kimia Asam Lemak pada Ikan Kakap Merah (Lutjanus). Chem. Prog. Vol. 11 No.2

Saraswati. (2013). Pemurnian Minyak Ikan Lemuru (Sardinella lemuru) menggunakan Sentrifugasi dan Adsorben Bentonit. Institut Pertanian Bogor.

Sari, R. N., Sediadi, B., Utomo, B., \& Basmal, J. (2016). Refining of Pangasius Oil from Fish Smoking By-products. 171182.

Sartika, D. R. A. (n.d.). Pengaruh Asam Lemak Jenuh, Tidak Jenuh dan Asam Lemak Trans terhadap Kesehatan. 16424.

Sindt, G. L. (n.d.). Environmental issues in the rendering industry Gregory L. Sindt, P.E. Environmental Engineer Bolton and Menk, Inc.

SNI 01-2891-1992. Cara uji Makanan dan Minuman.

Suroso, A. S. (2013). Kualitas Minyak Goreng Habis Pakai Ditinjau dari Bilangan Peroksida, Bilangan Asam dan Kabar Air. Jurnal Kefarmasian Indonesia, 3(2):77-88

Thammapat, P., Raviyan, P., \& Siriamornpun, S. (2010). Proximate and fatty acids composition of the muscles and viscera of Asian catfish ( Pangasius bocourti ). Food Chemistry, 122(1), 223-227. https://doi.org/10.1016/j. foodchem.2010.02.065

Sarungallo, Z. L. (2015). Pengaruh metode ekstraksi terhadap mutu kimia dan komposisi asam lemak minyak buah merah (Pandanus conoideus). Jurnal Teknologi Industri Pertanian, 24(3). 